

\title{
Creativity of Interactive Academic Education for Sustainable Urban Development
}

\author{
Bujar Bajçinovci ${ }^{{ }^{*}}$ \\ ${ }^{1}$ University of Prishtina, "UP”, Faculty of Civil Engineering and Architecture, Kosovo. \\ "Email: bujar.bajcinovci@uni-pr.edu
}

\begin{abstract}
Cities are multiplex ecosystems driven by our daily life style, which directly reflect in our health, resources, economics, social and community services. It can be spatially considered that cities are unique and regionally specific. Education for sustainable development is a process with a primary role to protect and use of environment, to manage spatial planning and urban development as a whole holistic system. In relation to education for sustainable development, creativity of urban planning and design can significantly improve quality of life of their urbanites. Hence, students and teachers are an epic symbiosis in a process of teaching and learning. Actually, this interaction can be more bonded and interdependent with high-tech didactic tools. The digital era has implemented in the education system new creative methods of learning, a new way of life and style in schooling. The relationship between a student of architecture and teachers broadened more with introduction of computer aided design and simulation tools in presenting those ideas into the reality. The new millennium began a crucial activity for the city of Prishtina in terms of urban, demographic and socio-spatial phenomenon's. The research methods consist of empirical observation carried out during 25 years of experience in academia, and direct observation of teaching methods. The purpose of this paper is to examine the teaching process, with the focus on creativity of interactive education for sustainable development. Findings indicate that through an informal meeting places for interactive education, the teaching process in architectural studies can bring more: sustainable development and awareness of space, a didactic process which bonds multidimensional threads between students and teachers; thus, strengthening a powerful sense of partnership, avoiding boredom and passive learning, while facing the real day to day challenges, accompanied with the development of technology, life style, and global world trends. Research concludes that uniform old teaching platform, cannot respond to all specific issues faced by students in this globalisation era. Therefore, new teaching strategies must involve interactive education for sustainable development, and education research as a new partnership, a new working holistic system between students and teachers, thus, working together simultaneously towards continuous improvement of academia processes, answering to the needs of new globalisation era.
\end{abstract}

Keywords: Education, Teaching, Sustainable Urban Development, Creativity, Prishtina.

\section{INTRODUCTION}

Students and teachers are an epic symbiosis in process of interactive teaching and learning.

What is the essence of this interaction? Surely, it is not a question with a simple answer (Bajçinovci, Jerliu 2017). Actually, this interaction is more bonded and interdependent with technology and accessories, which in a whole didactic process expands learning horizons. In the field of architecture, introduction of computer aided design has opened new 
opportunities for the creativity, and opportunities. Architects, as the preeminent computer aided design users, developed into the creation of the new innovative software, which carry out to their need for creative expression in sustainable urban development. Cities are multiplex ecosystems driven by our daily life style, which directly reflect in our health, resources, economic, social and community services. They are open consolidated systems and extensive organisms with specific and multiplex metabolism that consume enormous amount of energy, generate excessive amount of waste, originate a sum of impromptu environmental phenomenon, and activities (Bajçinovci, Jerliu 2016).

Cities can be spatially treated as unique zones, and regionally different. Urban sustainable development is a process with a primary role to preserve the environment, to administer spatial planning and urban framework as a whole holistic system. In relation to teaching education for sustainability (Iliško, Badjanova, 2017) creativity of urban planning and design can significantly improve quality of life of their urbanites. In this context, the question is, what should be exactly the role of the interactive education for sustainability. Thus, the whole didactic process remains open for creative expression in to the architectural schools. Architecture and urban design are the most intriguing branch of sciences for exploring interactive conceptual teaching varieties, which visually can be presented and implemented in education for promoting the sustainability.

Furthermore, for the future perceiving of academia's role, it is crucial to be presented and implemented an unorthodox curriculum or a non-common way of transmitting knowledge. Hence, we argue that new contemporary academia challenges should encourage a brand new complementary studies, using and developing new action research theories (Salite, 1993 - 2015; Pipere and Salite, 2006; Salite, Micule et al. 2007; Grisane, 2007; Belousa, Olehnovica et al., 2007; Salite, Gedzune and Gedzune, 2009; Salite, Ignatjeva, and Salitis, 2009; Salite, Gedzune, and Gedzune, 2010; Gedzune, G. et al., 2011; Kapenieks and Salite, 2012; Badjanova, Ilisko, and Drelinga, 2013; Kravale, Ilisko, and Olehnovica, 2013; Pipere, Veisson, and Salite, 2015; Gedzune, G., 2015; Gedzune, I., 2015; Briede, 2015; Zarina, Drelinga, Iliško, and Krastina, 2016), strengthened with actions towards the exploitation of all resources, especially in nurturing cognitive development, in order to provide a better learning processes. Creativity of interactive education for sustainable urban development presents the necessity of evolving the metropolitan cities, presenting a much-needed holistic development for students, with a primary aim to preserve the environment, quality of life, and the whole system of social wellbeing (Bajçinovci, Jerliu 2016). 
The other fundamental part on the interactive teaching creativity for students of architecture is the comprehension of the 'trend' and the background of its absorption in the teaching process. The intangible beliefs and impulse patterns of society over centuries have always had the strong causatum on values of what is a trend and what is 'in'. A great influence of unorthodox education in the architecture field has over millennia emerged a consequence of development of unconventional ideas, which became a measure for society evolution, and academic liberties with new trends and new ways of methods for teaching. We argue that progress of technology in history has always had contrasting and strange encounters, hence, a breakthrough in progress has been made when great ideas was generated by lateral thinking (De Bono, 2015). According to the Hewett, in Curricula for Human-Computer Interaction, which stated: "Because human-computer interaction studies a human and a machine in communication, it draws from supporting knowledge on both the machine and the human side. On the machine side, techniques in computer graphics, operating systems, programming languages, and development environments are relevant. On the human side, communication theory, graphic and industrial design disciplines, linguistics, social sciences, cognitive psychology." (Hewett et al. 1992-1996).

\section{MATERIALS AND METHODS}

The research presented in this paper reflects interactive methods in education for sustainable development, especially in architecture, creativity and innovation in academic teaching. Emphasizing interactive partnership learning methods in-between teachers and students. The research methods consist of empirical observation carried out during 25 years of experience in academia, direct observation of teaching methods, and promoting contemporary interactive teaching methods. To perceive a clearer research data, exploring was made within the department of architecture, in the University of Prishtina, Faculty of Civil Engineering and Architecture, in the context of the possibilities for the improvement of the curricula's, within adapted and accredited academic frameworks. Creativity of interactive education for sustainability in architectural studies was explored through review of timeline of academic workshops, curricula's, and within studio researches of the students in Master programme of the department of architecture in the University of Prishtina. Supplementary research data was provided from: studies of the urban structure of the University Campus, pioneering steps of interactive teaching for sustainable architecture which I taught in Master courses, the contemporary building systems as a part of curricula which I have developed, actions for preserving the local environment features, and attributes of spatial planning for the city of the Prishtina. 
With this paper the objective was to present a retrospective of evolution of teaching methods in academia. Furthermore, describing the teaching methods with the emphasis on creativity in education, which directly was reflected on actions for sustainable urban development. Moreover, there is a significant point to argue that the complexity and interactive teaching varieties of present situation cannot be fully described, without a comprehensive, multidimensional, and transdisciplinary academic discourses (Salite, 2009; Bajçinovci, Jerliu 2017).

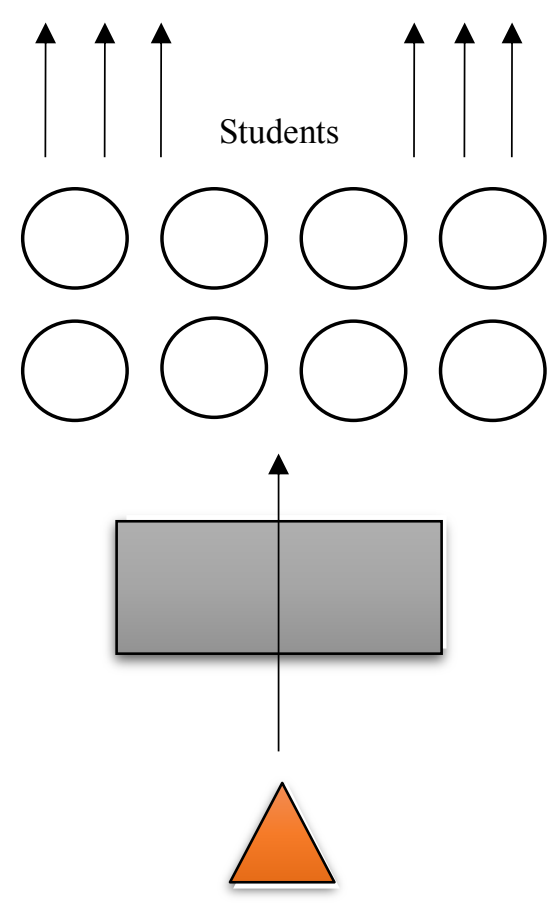

a. Lecturer

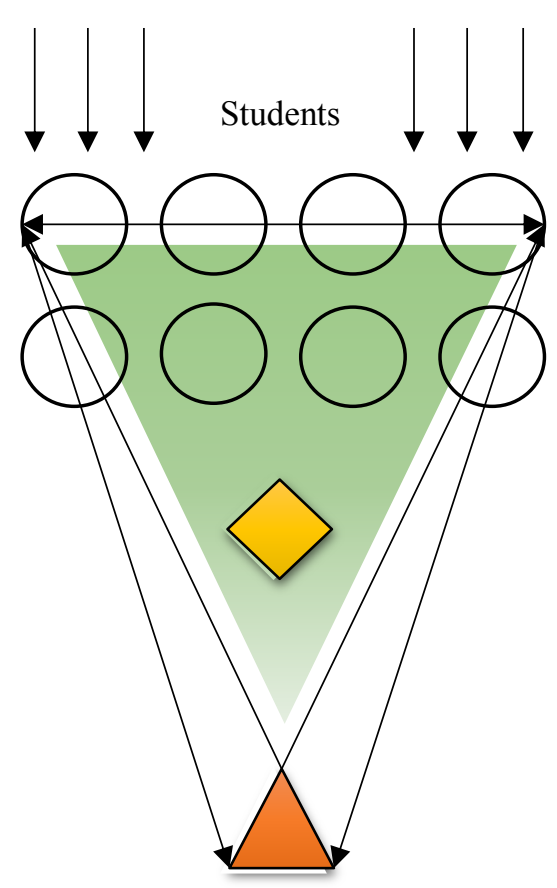

b. Lecturer

Figure 1. (a) Traditional teaching methods, (b) Interactive teaching methods with a model as an artefact in sustainable development (Bajçinovci, Jerliu 2017).

In Figure 1-a, we can clearly observe that there is one-way communication between lecturer and students, which is not the case in Figure 1-b, where communication between students and lecturers are interactive, thus, forming active partnership in-between. In terms of integration, an integrated process of organizing partnership into a functional system is a system that requires new solutions for problems, nurturing for adapting and evolving strategies. Integrated framework process implies partnership between students and teachers, with clearly identified priorities, which were in the process explored in enough qualitative iterations, seeking for the best solutions for the academic and professional dilemmas and problems. Many authors, claim that the iteration is the key to understand the complexity of the cognitive process, (Wolfram, 2002) indicates that the iterative process, the application of simple rules, is at the heart of the mysterious ability of nature, in the 
production of multiplex phenomena and processes. Iterations of the "structure, function, and process in a given context would examine assumptions and properties of each element in its own right, then in relationship with other members of the set. Subsequent iterations would establish validity of the assumptions, then compatibilities and/or conflicts are identified and dissolved" (Gharajedaghi, 2006).

Dissolving conflicts may require re-conceptualization of the variables involved, finally, successive iterations will produce an integrated holistic solution. Successive iteration would output a greater awareness and more analogous to the nature of the whole. Further, these iterations, then, are like a reverse loupe through which we see the system we are trying to understand as a working part of successively bigger picture as presented in Figure 2 (Gharajedaghi, 2006; Bajçinovci, Jerliu 2016).

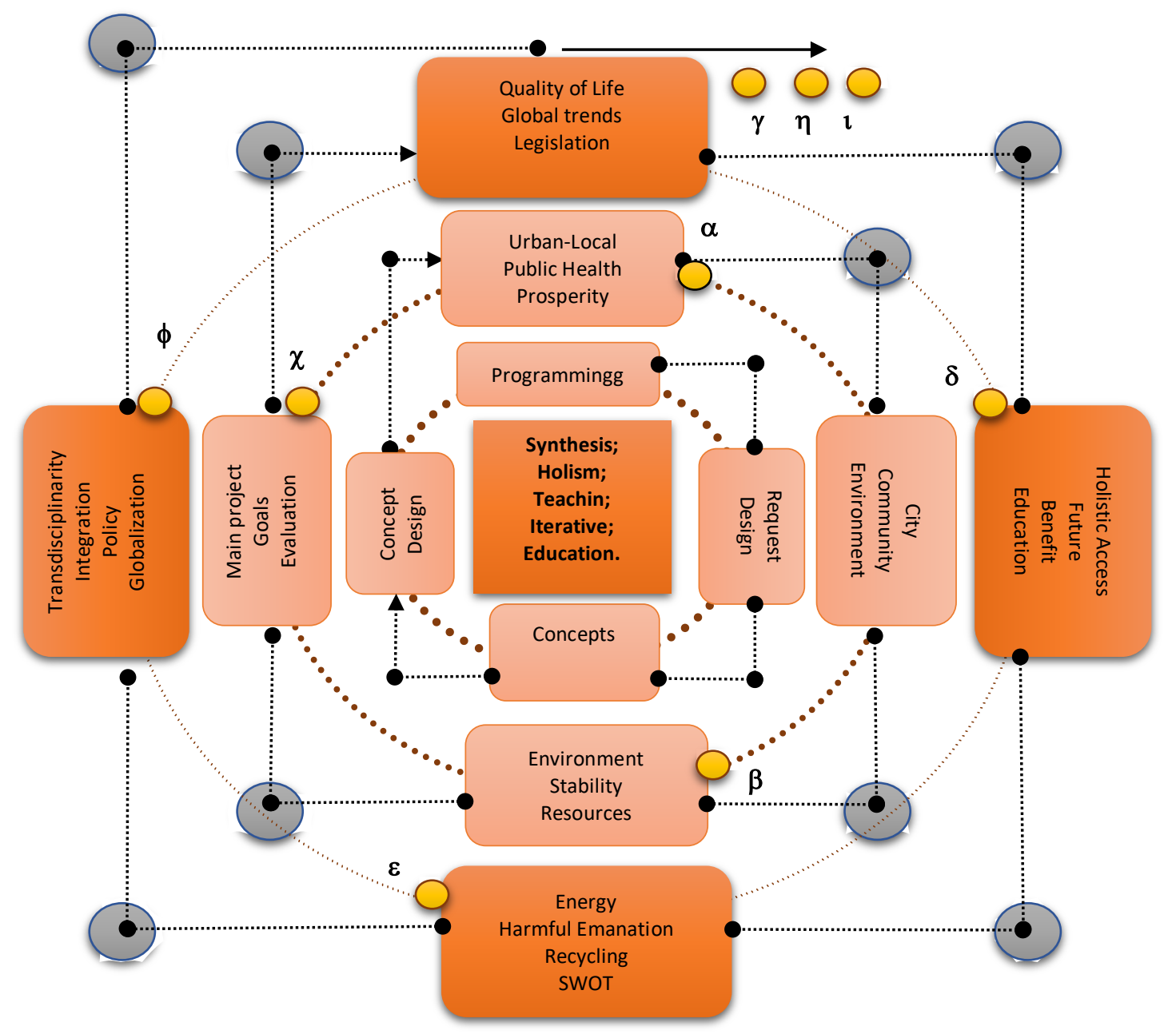

Figure 2. Complexity of iterative model: Actions to exploit transdiciplinarity on teaching for sustainable development processes. (Gharajedaghi, 2006; Bajçinovci, Jerliu 2016).

According to the result presented in Table 1, there is a lack of variety of courses in organization of the study programme, therefore we need a substantial rethinking of what we have to offer as an academia and teaching staff. 
Table 1.

Students satisfaction with current study programme. (Eurostudent.eu/113, 2016).

\begin{tabular}{lllll} 
& $\begin{array}{l}\text { (Very) } \\
\text { Well }\end{array}$ & $\begin{array}{l}\text { Fairly } \\
\text { satisfied }\end{array}$ & $\begin{array}{l}\text { (Some) } \\
\text { Dissatisfied }\end{array}$ & Total \\
\hline & percent & percent & percent & percent \\
\hline $\begin{array}{l}\text { 1. Quality of teaching } \\
\text { 2. Organization of } \\
\text { studies }\end{array}$ & 48.9 & 33.5 & 17.6 & 100 \\
\hline 3. Variety of courses & 26 & 31.4 & 27 & 100 \\
\hline 4. Study facilities & 38.6 & 23 & 51 & 100 \\
\hline
\end{tabular}

In addition of design processes and creative impacts which design is fundamentally refined to do, (Simon, 1996) also has argued this phenomenon: "Design is indeed a ubiquitous activity. In the physical world every artefact, a miniature silicon sensor for invasive blood pressure monitoring, an automobile, or a building, is the result of some kind of design activity. Any problem-solving situation in which there exists an element of the unknown, such as lack of information or incomplete knowledge of the relationships among issues, involves an intellectual effort that can be categorized as design" (Simon, 1996; Bajçinovci, Jerliu 2016).

\section{DISCUSSION}

The eye works more or less like a camera. The cornea acts like a glass lens and is the equivalent of the camera's outer lens. The pupil corresponds to the diaphragm and the lens of the eye corresponds to the inside lenses of the camera. The retina is comparable to the film located inside the camera. People spend most of the day at home with a lighting ranging from 50 to 500 lux. Light determines the pace of the biological clock and may have an effect on the circadian system. As stated in many cases and from may authors light is life, good lighting is important to see the world around us, what we want to see needs to be illuminated. Good lighting also affects the way we feel, it also helps in the style and quality of life. Since the first appearance of possibilities that students of architecture can visualize their own ideas, and computations with machines, a new way of thinking has begun, obviously, very hard acceptance in the beginning. This process of creative expression with digital tools, was considered as a heresy among orthodoxy hand drawing architects. But, new digital era offered enormous varieties and creative potentiality, which made possible the design of a rather same architectural model with infinite variations, empowered from 
computational algorithms. Furthermore, such digital models and design patterns generated by software algorithms had evolved into much more contemporary futuristic concepts. The reasoning and acceptance of new teaching methods of what design can do is in constant evolution; we think here about a contemporary industrial revolution, or just about a different way of model perception. According to the Terzidis: "Such a possibility opens enormous potential than has not been previously possible. Rather than utilizing mere human-based intelligence in resolving design problems, a complementary synergetic relationship between humans and computers becomes possible” (Terzidis, 2006). Hence, in such framework of students and teachers, both participants can contribute to unique solving dilemmas and research problems, strengthened with efforts to seek more, explore, invent, or apply new principles and methods in science. Creative interacting process becomes the essential link between the two parties, in teaching and learning (Terzidis, 2006; Bajçinovci, Jerliu 2017). Interactive teaching methods in architecture, from this context, we can exploit endless possibilities to improve the education process. Hence, we identify four key attributes for sustainable urban development, in simulating relevant scenarios:

- Variety of ideas, generation of many iterations, seeking for problem solving;

- Creative improvement, liberty of generation of conceptual research models;

- $\quad$ Research visual modelling in early stages of lateral thinking;

- Generation a various possibility in SWOT analysis.

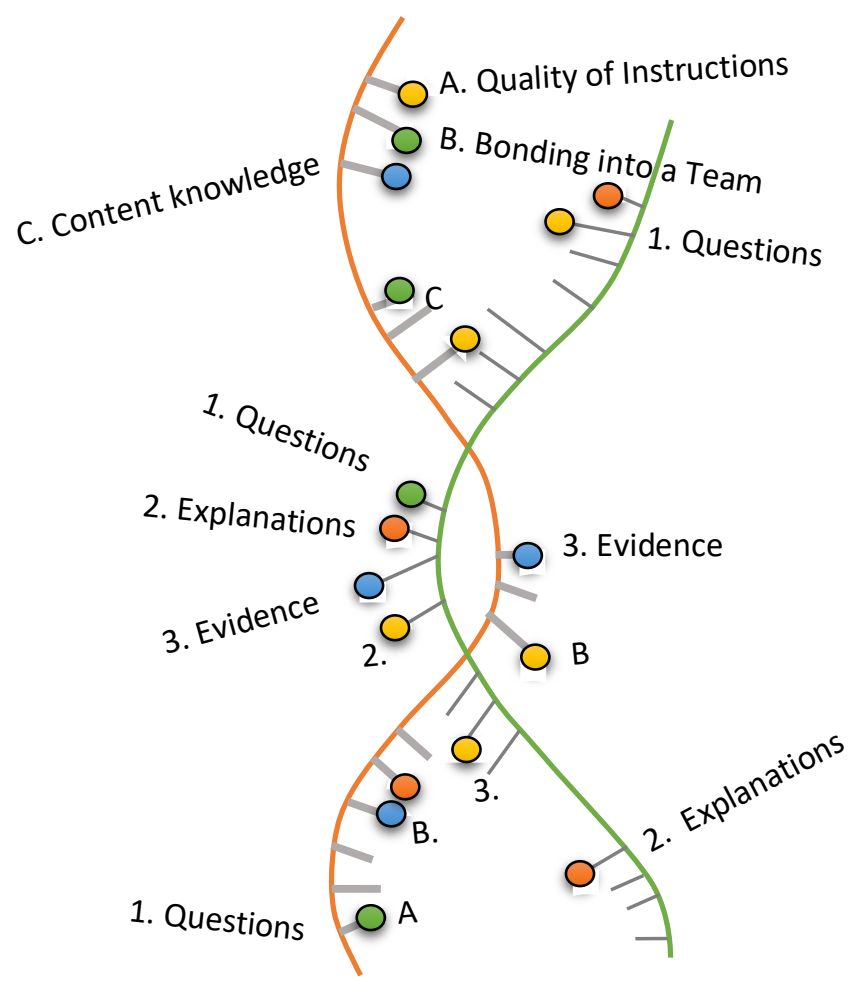

Figure 3. Structure of complex bonding threads, in evolutive partnership, teachers and students. 
Current issues of improving the teaching quality and the introduction of completely new education concepts, demands a new fundamentally approach of integrated and holistic engaging for students and teachers (Iliško, 2005), into a creative group to respond to a new contemporary challenge.

The process of integrating aims to include all possible attributes of the research problem, so that any decision in the design process has to identify as many diversities of action. The holistic process is associated with activities of all parties involved in the project, with objective to transform the nature of teaching, respectively, to adopt a new approach in solving urban sustainable development dilemmas on presented situation with specific requirements. "Education, of course, is always based on what was. Education shows you what has been and leaves you to make the deduction as to what may be. Education as we pursue it cannot prophesy, and does not" (Wright, 1955).

The architectural design has always been a pioneer of social change on basis of what is called the modern and urban style. In terms of quality of life, the integrated process of cooperation between students and teachers (Iliško, 2007), will try to find the best solutions available for specific and unique problem, given the fact that never before as today, we have multifunctional and hybrid structures as a result of the globalization, and trend, strengthened with technology advancement. Therefore, those phenomena can realistically do impact on the global market, seriously affect the global economics. So, a whole global networked system is holistically interacting with a wide subsystem that forms international labour market.

Nowadays, in front of the students stand a new complex structure of social challenges where student must be proactive key participant of future pedagogy, hence, those challenges does require redefining framework between students and teachers in a wide background of academia. Surely, this was validated and pursued by many countries in Europe, presenting their arguments and demands imposed by the European Educational Standards in accordance with Bologna and Lisbon conventions. This visionary and contemporary academic framework must also be encouraged and implemented in Kosovo universities.

According to the data presented in Table 2, there is a good belief of chances on labour market after graduation from current study program on the field of natural and engineering sciences. 
Table 2.

Bachelor student's assessment of chances on labour market after graduation. Actual programmes by field of study. (Eurostudent.eu/119, 2016; Bajçinovci, Jerliu 2017).

\begin{tabular}{lllllll} 
& $\sum$ & Education & Humanities & Social & Natural & Engineering \\
\hline & $\%$ & $\%$ & $\%$ & $\%$ & $\%$ & $\%$ \\
\hline 1. (Very) Good & 18.6 & 14.1 & 15.6 & 18 & 25.9 & 23.5 \\
\hline 2. Fair & 25.6 & 28.2 & 25.5 & 23.7 & 22.4 & 31.9 \\
\hline $\begin{array}{l}\text { 3. (Very) Poor } \\
44.6\end{array}$ & 46.4 & 46.5 & 50 & 41.4 & 34.7 \\
\hline $\begin{array}{l}\text { 4. Unable to } \\
\text { rate }\end{array}$ & 11.2 & 11.3 & 12.4 & 8.2 & 10.3 & 10 \\
\hline Total & 100 & 100 & 100 & 100 & 100 & 100 \\
\hline
\end{tabular}

\section{Urban Boom}

Spatial and urban development of the city Pristina, in the past has not been the objective of research in scientific programmes. Chronologically, it's important to evident the actions of spatial and urban planning, city of Prishtina:

- $\quad$ Pristina's development plan, (1937). Included the area of 192.72 ha and was programmed for population of 16,000 inhabitants;

- The second development plan, (1948). No trace of the existence of this documentation;

- General urban design, (1953). The timeline of spatial plan was up to 1980, planned for 50,000 inhabitants in the area of $950 \mathrm{ha}$;

- Directive plan for traffic and city dedicated zones, (1967). With action plan for 100,000 inhabitants;

- In 1969, the directive plan for city dedicated zones, was replaced by General Urban Plan;

- The overall urban plan and spatial development plan in 1988, approved for the timeline to year 2000, considering for 225,000 inhabitants, (Municipal of Prishtina, 2004).

The last two decades, have brought a variety of phenomena for the city of Prishtina, primarily demographic, social, environmental and political. The socio-demographic and spatial boom in 2000 , the process of uncontrolled growth of the city, are symptom and result of major cities after major events, like war for example. "According to the estimate of the OSCE (Extrapolated level growth of former population in Kosovo 2\%/yr.), city of Prishtina in 2000 had 545,477 inhabitants" (Municipal of Prishtina, 2004). 
Thus, there are persistent institutional activities and municipal actions on the strategic development plans for the city. The new millennium began with crucial activities for Pristina, in terms of demographic and urban development. The city is experiencing a multiplex change in all possible social fields. Being the capital city of Kosovo, in a very short time the population of Prishtina has nearly doubled, adding every day approximately another $30 \%$ of the population coming in the city for work, possible settlement, and migration.

\section{CONCLUSION}

The actual state of academia, and education requires specific contemporary activities, especially when the situation is directly linked to the quality of teaching and future challenges of the labour market. Formally fulfilling legal academic standards, within adapted and accredited academic frameworks, cannot be expected to solve comprehensive and future challenges, associated with the development of technology, labour market, life style, and global world trend. Findings in this paper indicate that through interactive teaching methods as contemporary learning strategies can strengthen the partnership in between academia and sustainable urban development. An informal meeting places for education, can concurrently present a teaching strategy by which we can bring more: conceptual awareness for urban space, interactive contemporary learning, which bonds complex connected threads between students and teachers in education. Thus, one and the same, and moderately new education strategy, cannot respond to all specific problems faced by day to day student's issues, academia, and future labour market. Therefore, new teaching strategies must involve a new partnership, a brand new and more refining holistic system, as a response to less functional academic system in this globalisation era. Partnership, a new symbiosis between students and teachers must prevail, working together simultaneously on continuous improvement of teaching and learning processes. Inadequate and not comprehensively solving the problems of a given task, not only drops the current dilemma, but also has a negative impact on future generations as well. Not adequately solving the specific problems of the actual time, results in mega problems as heritage for future generations. The current resolution of the actual situation with the classic teaching methods, formally fulfilling academic, and legal standards, requires a serious approach of academia for the comprehensive future education challenges. Specific city problems will require specific, unique, and original solutions. The current degraded state of the environment and urban fabric requires immediate scientific sustainable actions strengthened with the reformed teaching methods of academia, emerging specific 
responsibilities and activities, especially when the urban situation is directly linked to the quality of life and public health.

\section{REFERENCES:}

Badjanova, J., Ilisko, Dz., and Drelinga, E. (2014). Holistic approach in reorienting teacher education towards the aim of sustainable education: the case study from the regional university in Latvia, Proceedings of the 5th World Conference on Educational Sciences, 116, 2931-293, DOI: 10.1016/j.sbspro.2014.01.682.

Bajçinovci, B., Jerliu, F. (2016a). Challenges of Architectural Design in relation to Environment and Air Pollution. A Case study: Prishtina's first public parking garage. Journal of Science, Humanities and Arts. Freiburg. Germany, DOI: 10.17160/josha.3.7.254.

Bajçinovci, B., Jerliu, F. (2016b). Achieving Energy Efficiency in Accordance with Bioclimatic Architecture Principles. Environmental and Climate Technologies. Riga Technical University. DOI: 10.1515/rtuect-2016-0013.

Bajçinovci, B., Jerliu, F. (2017). The Concept of "Modelarium" and its Impact on Creativity and Artistic Education. Review of Artistic Education no.14 2017. De Gruyter. DOI: 10.1515/rae-2017-0030.

Bajçinovci, B., Jerliu, F. (2016c). Complexity of Iterative Model - Architectural Integrated Design as an Evolutive Transdisciplinary Strategy. Case Study: A City Without a River. JOSHA, Freiburg. Germany. DOI: 10.17160/josha.4.1.264.

Bajçinovci, B. (2017). Environment Quality: Impact from Traffic, Power Plant and Land Morphology, a Case Study of Prishtina. Environmental and Climate Technologies. Riga Technical University. DOI: 10.1515/rtuect-2017-0006.

Belousa, I, Olehnovica, E., Ilisko, Dz., \& Mizule, I. (2007). Gender equality in science curriculum: Recommendations of reorienting science education towards sustainable development. In A. Pipere (Ed.), Education and sustainable development: First steps toward changes, 2, 263-292.

Cimdina, G., Timma L., Veidenbergs I., Blumberga D. (2015). Methodologies Used Scaling-up From a Single Energy Production Unit to State Energy Sector. Environmental and Climate Technologies. Riga Technical University. DOI: 10.1515/rtuect-2015-0002.

De Bono, E. (2015). Lateral thinking, Creativity step by step. Harper Colophon; Reissue edition. ISBN-10: 0060903252, ISBN-13: 978-0060903251

EuroStudent. http://database.eurostudent.eu/export/113

http://database.eurostudent.eu/export/119 , (accessed 31 december 2017).

Gharajedaghi, J. (2006). Systems Thinking. Managing Chaos and Complexity. Elsevier.

Gedzune, G., Gedzune, I., Salite, I., \& Iliško, Dz. (2011). Exploring pre-service teachersí frames of reference and their orientation towards inclusion or exclusion: Educational action research journey. In Proceedings of the 9th JTEFS/BBCC conference Sustainable Development. Culture. Education: BBCC Mission Reorientation of Teacher Education and Research in Education for Sustainable Development, 18-21 May, 2011 (pp. 80-102). Siauliai, Lithuania: Vs Sauli universiteto leidykla, ISBN 978-609-430-077-6.

Hewett, T. et al. (1992-1996). ACM SIGCHI Curricula for Human-Computer Interaction. http://www2.parc.com/istl/groups/uir/publications/items/UIR-199211-ACM.pdf (accessed 30 december 2017). 
Iliško, D. (2005). Pedagogical challenges for implementing holistic curriculum in Latvia. Journal of Teacher Education and Training, 5, 28-39.

Iliško, D. (2007). Teachers as agents of societal change. Journal of Teacher Education for Sustainability, 7, 14-26. doi: 10.2478/v10099-009-0002-9

Iliško, D. \& Badjanova, Y. (2014). A case study of ESD implementation: Signs of sustainable leadership. Discourse and Communication for Sustainable Education, $5,38-48$.

Kapenieks, J. \& Salite, I. (2012). Action research for creating knowledge in an elearning environment. Journal of Teacher Education for Sustainability, 14(2), 11130.

Municipal Assembly of Prishtina. (2004). Urban Development of Prishtina 2004-2020. Online: http://www.bp-home.com/about/plani_urbanistik/plani_strategjik.pdf , Kosovo, (accessed 15 january 2017).

Pipere, A. and Salite, I. (2006) Educational action research in teacher education: Fostering research skills. Full papers of Asia-Pacific educational research association international conference 2006 iEducational research, policy and practice in an era of globalization: The Asia-Pacific perspectives and beyond.

Pipere, A., Veisson, M., and Salite, I. (2015). Developing research in teacher education for sustainability: UN DESD via the Journal of Teacher Education for Sustainability. Journal of Teacher Education for Sustainability, 17(2), 5-43, DOI: 10.1515/jtes-2015-0009.

Salite, I. (2000). Integrated teaching in ecosystem and spiritual context. Natural Sciences and

Teacher Training, Collected articles of the International conference. Part II April, 27-28, 2000, DPU: Saule.

Salite, I., Micule, I., M., Ilisko, D., and Stakle, A. (2007) Toward the sustainability in teacher education: Promise of action research. In Pipere, A. (Ed.), Education and sustainable development: First steps toward changes, Volume 2, Daugavpils University, 263-292.

Salite, I. (2008). Educational action research for sustainability: Constructing a vision for the future in teacher education. Journal of Teacher Education for Sustainability, 10, 5-17.

Salite, I. (2009). Teacherís perspectives on learning programs design for sustainability: The Latvia experience. Proceedings of the International conference iCitizenship, Multiculturalism, Cosmopolitanismî, November 3-4, 2008, Nikosia, University of Cyprus, Vol. 1, 145ñ158, ISBN 978-9963-9442-1-7.

Salite, I., Ignatjeva, S., \& Salitis, A. (2009). Broadening teachers views on sustainability through action research. Proceedings of the International conference of Citizenship, Multiculturalism, Cosmopolitanism, November 3-4, 2008, Nikosia, University of Cyprus, 1, 158ñ173, ISBN 978-9963-9442-1-7.

Salite, I., Gedzune, G., \& Gedzune, I. (2009). Educational action research for sustainability: seeking wisdom of insight in teacher education. Journal of Teacher Education for Sustainability, 11(2), 14-30, doi:10.2478/v10099-009-0037.

Salite, I., Gedzune, I., \& Gedzune, G. (2010). From personally relevant experience to action research for sustainable education. In M. Witthaus, K. McCandless, \& R. Lambert (Eds.), Tomorrow today. (pp. 95-98). Leicester: Tudor Rose, ISBN 09536140-8-5.

Salite, I. (2015). Searching for sustainability in teacher education and educational research: experiences from the Baltic and Black Sea Circle Consortium for educational research. Discourse and Communication for Sustainable Education, 6(1), 21-29, doi: 10.1515/dcse-2015-0002. 
Salite, I., Ilisko, Dz., \& Micule, I. (2015). ISE action research: Reorienting teachers dispositions towards ESD, Latvia. Leading practice publication: Professional development of university educators on Education for Sustainable Development in European countries, 105-107, ISBN: 978-80-87076-22-4, UE4SD Czech Republic.

Salite, I., Drelinga, E., Ilisko, Dz,. Olehnovica, E., Zarina, S., (2016). Sustainability from the Transdisciplinary Perspective: An Action Research Strategy for Continuing Education Program Development. Journal of Teacher Education for Sustainability, 18(2), 135-152, DOI: 10.1515/jtes-2016-0020.

Terzidis, K. (2006). Algorithmic Architecture. Architectural Press. Taylor \& Francis. New York.

Wright, Lloyd, F. (1955). https://christen.community.uaf.edu/2013/05/26/frank-1loydwrite-on-education/, (accessed 30 december 2017).

Wolfram, S. 2002. A New Kind of Science, http://www.wolframscience.com/nksonline/toc.html, (accessed 30 december 2017).

Zarina, S., Drelinga, E. Ilisko, Dz., \& Krastina, E. (2016). Teachers vocation and students' attitudes towards a choice of teacher's vocation. Proceedings of the International Scientific Conference: Society. Integration. Society. The Scientific Journal of Rezekne Academy of Technologies. Rezekne: Rezekne Academy of Technologies, DOI: http://dx.doi.org/10.17770/sie2016vol1.1498. 